\title{
Hemoparasites in ticks of wild birds of Serra dos Órgáos National Park, state of Rio de Janeiro, Brazil
}

\author{
Hemoparasitos em carrapatos de aves silvestres do Parque Nacional da Serra dos Órgáos, estado do \\ Rio de Janeiro, Brasil \\ Adlilton Pacheco ${ }^{1}$; Matheus Dias Cordeiro ${ }^{1}$; Marcio Barizon Cepeda ${ }^{1}$; Hermes Ribeiro Luz ${ }^{2}$; \\ Sergian Vianna Cardozo ${ }^{3}$; Bruno Pereira Berto ${ }^{1,4}$; Alexandro Guterres ${ }^{5}$; Adivaldo Henrique da Fonseca ${ }^{1 *}$ (C) \\ ${ }^{1}$ Departamento de Epidemiologia e Saúde Pública, Universidade Federal Rural do Rio de Janeiro - UFRRJ, Seropédica, RJ, Brasil \\ ${ }^{2}$ Departamento de Medicina Veterinária Preventiva e Saúde Pública, Universidade de São Paulo - USP, São Paulo, SP, Brasil \\ ${ }^{3}$ Programa de Pós-graduação em Biomedicina Translacional, Departamento de Saúde, Universidade do Grande Rio - \\ UNIGRANRIO, Duque de Caxias, RJ, Brasil \\ ${ }^{4}$ Departamento de Biologia Animal, Universidade Federal Rural do Rio de Janeiro - UFRRJ, Seropédica, RJ, Brasil \\ ${ }^{5}$ Laboratório de Hantaviroses e Rickettsioses, Fundaçâo Oswaldo Cruz - FIOCRUZ, Rio de Janeiro, RJ, Brasil
}

Received November 26, 2018

Accepted March 01, 2019

\begin{abstract}
The aim of this study is to detect the presence of tick-borne agents of genera Rickettsia, Borrelia, Babesia, Ehrlichia and Anaplasma in ticks collected from native wild birds in the state of Rio de Janeiro. Birds were captured and observed carefully to find the ectoparasites. DNA detection of hemoparasites was performed by means of the polymerase chain reaction (PCR). The sequences obtained were analyzed and their homologies were compared to the available isolates in the GenBank platform database. A total of 33 birds were captured from 20 different species, of which 14 were parasitized by Amblyomma longirostre $(\mathrm{n}=22)$. There was absence of DNA from agents of the genera Babesia, Anaplasma and Ehrlichia in the evaluated samples. The phylogenetic analysis indicated that one sample had $100 \%$ identity with Rickettsia bellii (KJ534309), the other two samples showed 100\% identity with Rickettsia sp. Aranha strain and strain AL (EU274654 and AY360216). The positive sample for R. bellii was also demonstrated to be positive for Borrelia sp., which presented a similarity of $91 \%$ with Borrelia turcica (KF422815). This is the first description of Borrelia sp. in ticks of the genus Amblyomma in South America.
\end{abstract}

Keywords: Conservation units, ectoparasites, rickettisiae, Borrelia.

\section{Resumo}

Este trabalho teve como objetivo detectar evidências moleculares da presença de agentes dos gêneros Rickettsia, Borrelia, Babesia, Anaplasma e Ehrlichia transmitidos por carrapatos coletados de aves silvestres no estado do Rio de Janeiro. Aves foram capturadas e observadas cuidadosamente a procura de ectoparasitos. A detecçáo de DNA de hemoparasitos foi realizada por meio da reação em cadeia da polimerase (PCR). As sequências obtidas foram analisadas e sua homologia comparada aos isolados disponíveis na base de dados da plataforma GenBank. Foram capturadas 33 aves, de 20 espécies diferentes das quais 14 estavam parasitadas por Amblyomma longirostre $(\mathrm{n}=22)$. Houve ausência de DNA de agentes dos gêneros Babesia, Anaplasma e Ehrlichia nas amostras avaliadas. A análise filogenética indicou que uma amostra apresentou $100 \%$ de identidade com Rickettsia bellii (KJ534309), as outras duas amostras apresentaram 100\% de identidade com Rickettsia sp. cepa Aranha e Cepa AL (EU274654 e AY360216.). A amostra positiva para R. bellii também apresentou positividade para Borrelia sp. que apresentou similaridade de $91 \%$ com Borrelia turcica (KF422815). Esta é a primeira descrição de Borrelia sp. em carrapatos do gênero Amblyomma na América do Sul.

Palavras-chaves: Unidades de conservação, ectoparasitos, rickettisiae, Borrelia.

\footnotetext{
*Corresponding author: Adivaldo Henrique Fonseca. Departamento de Epidemiologia e Saúde Pública, Instituto de Veterinária, Universidade Federal Rural do Rio de Janeiro - UFRRJ, Campus de Seropédica, BR 465, Km 7, Bairro Ecologia, CEP 23891-000, Seropédica, RJ, Brasil. e-mail: adivaldofonseca@yahoo.com
} 


\section{Introduction}

Birds are host to a wide variety of ticks, especially when the latter are in the larva and nymph stages. Therefore, this plays an important role in the epidemiology of several important diseases for veterinary and public health (LABRUNA et al., 2007; OGRZEWALSKA et al., 2010; SANCHES et al., 2013; CAPLIGINA et al., 2014). Moreover, studies worldwide have reported the importance of wild birds in the expansion of tick-borne diseases, such as anaplasmosis, babesiosis, Lyme disease, spotted fever, and tick-borne encephalitis (PAROLA et al., 2013).

By limitations in displacement, ticks also use their hosts to overcome numerous geographical barriers. In recent years, studies of tick-bird associations have been increasing exponentially, due to their importance in the dispersal and maintenance of the different tick species, and (consequently) their passengers' pathogens (HUBÁLEK, 2004; LOSS et al., 2016; BUDACHETRI et al., 2017).

In Brazil, studies on the diversity of ticks on birds have been carried out in several biomes (Atlantic Forest, Amazon, Caatinga, Cerrado, and Pantanal), with the immature stages (larva and nymph) of the genus Amblyomma being found to be the most common (LABRUNA et al., 2007; OGRZEWALSKA et al., 2010; LUZ et al., 2012; LUGARINI et al., 2015; RAMOS et al., 2015). Moreover, studies on infectious pathogenic agents in ticks that parasitize birds in Brazil are mainly concentrated in the detection of rickettsial agents (OGRZEWALSKA et al., 2008). Other agents of the genera Borrelia, Anaplasma and Ehrlichia were also detected in ticks that were parasitizing wild birds. In North America and parts of Europe, the DNA of these agents was detected in these arthropods, which were collected from birds (SCOTT et al., 2010; PALOMAR et al., 2012; ERWIN et al., 2016). Moreover, the species of ticks found on birds can also parasitize humans (GUGLIELMONE et al., 2006). For these reasons, there is a need for studies that characterize organisms that infect ticks found on birds, to enable a better understanding of the diversity and ecology of the zoonoses transmitted by these arthropods. Thus, the objective of the present work is to detect (through molecular techniques) hemoparasites present in ticks from birds of the municipality of Guapimirim and Serra dos Órgãos National Park in the state of Rio de Janeiro, Brazil.

\section{Material and Methods}

The study was carried out in the municipality of

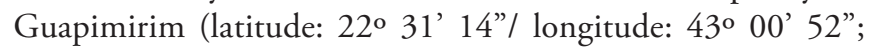
altitude 256 meters) and in the Serra dos Órgãos National Park

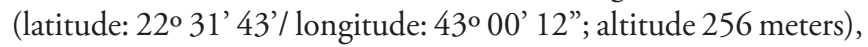
both of which are located in the state of Rio de Janeiro, Brazil. Three field visits, each lasting four days, were conducted between March and September 2016 at the place of study.

The birds were captured between 06:00 and 17:00 hours, using $5-20$ ornithological mist nets model $(12 \mathrm{~m}$ long $\times 3 \mathrm{~m}$ wide, with 16 and $36 \mathrm{~mm}$ mesh). The birds were then photographed and identified following the recommendations based on the nomenclature approved by the Brazilian Committee of Ornithological Records
(CBRO, 2014). Each bird was examined for the presence of ticks. If any were found, they were removed with forceps and placed in $1.5 \mathrm{~mL}$ polyethylene tubes containing absolute alcohol for later identification. Samples were initially stored at room temperature for up to four days. After collecting the ticks, the birds were released at the same collection site. All procedures were performed with live birds.

In the laboratory, the ticks were microscopically examined for identification, using a dichotomous key published by Martins et al. (2010) with the aid of a stereoscopic microscope. After identification, the arthropods were stored in RNA stabilization solution and frozen until processed for molecular analysis.

The ticks kept in RNA later were washed in distilled water three times and rehydrated in $200 \mu \mathrm{L}$ of phosphate buffered saline (PBS). The ticks were then individually placed in $1.5 \mathrm{~mL}$ polyethylene tubes. Next, $2 \mathrm{~mm}$ zirconium oxide beads and $80 \mathrm{mg}$ of $0.1 \mathrm{~mm}$ glass beads were added, both autoclaved, for trituration in Minibeadbeater BIOSPEC ${ }^{\circledR}$ for $1 \mathrm{~min}$.

Cell lysis was performed with the addition of $250 \mu \mathrm{L}$ of digestion solution $(20 \mathrm{mM}$ Tris- $\mathrm{HCl}, 20 \mathrm{mM}$ EDTA, $400 \mathrm{mM} \mathrm{NaCl}, 1 \%$ sodium dodecyl sulphate, $10 \mathrm{mM} \mathrm{CaCl}_{2}$ ) with $20 \mu \mathrm{L}$ of proteinase $\mathrm{k}(20 \mathrm{mg} / \mathrm{mL})$ in incubation overnight at $56^{\circ} \mathrm{C}$. The DNA was extracted by a phenol treatment and another phenol-chloroform treatment followed by precipitation with isopropanol. The DNA pellet (formed after centrifugation of $16000 \mathrm{xg}$ ) was washed twice with $70 \%$ alcohol and re-suspended in $100 \mu \mathrm{L}$ of elution buffer (10 mM Tris- $\mathrm{HCl}, 0,5 \mathrm{mM} \mathrm{EDTA} \mathrm{pH} \mathrm{9,0)} \mathrm{in} \mathrm{overnight} \mathrm{at} 4{ }^{\circ} \mathrm{C}$, as according to Santolin et al. (2013).

The extracted DNA was tested by a battery of PCR assays that were targeting microorganisms of the genera Rickettsia, Borrelia, Ehrlichia, and Babesia. For this task, specific primers were used for each agent, following the original protocol of each primer (Table 1).

Reactions were carried out using reagents from the PROMEGA ${ }^{\circledR}$, and each reaction contained $3 \mu \mathrm{L}$ de DNA, $14,2 \mu \mathrm{L}$ of water, $2 \mu \mathrm{L}$ de primers $(10 \mu \mathrm{M} \mathrm{F}+\mathrm{R}), 2,5 \mu \mathrm{L}$ of buffer (10X concentrado), $1,25 \mu \mathrm{L}$ of $\mathrm{MgCl}_{2}(50 \mathrm{mM})$ and $2 \mu \mathrm{L}$ of dNTP's $(2,5 \mathrm{mM})$, and $0,15 \mu \mathrm{L}$ Taq DNA polimerase (PROMEGA ${ }^{\circledR}$ ), in a final volume of $25 \mu \mathrm{L}$.

The amplified products were visualized in 1.5\% agarose gel, which were stained with ethidium bromide and visualized in a UV-Transilluminator.

Polymerase chain reaction positive samples were submitted to sequencing and phylogenetic analyses. Multiple sequence alignments were performed with the sequences obtained from this study and sequences from GenBank using MUSCLE, using the SeaView v.4 software program (GOUY et al., 2010). The best-fit evolutionary model was determined using MEGA version 7, using the Bayesian information criterion (KUMAR et al., 2016). Phylogenetic relationships were estimated using (a) Maximum likelihood (ML) phylogenetic inference that used PhyML, which was implemented in SeaView (GOUY et al., 2010) and (b) a Bayesian Markov chain Monte Carlo (MCMC) method implemented in MrBayes v.3.2.6 (SOARES et al., 2015). The MCMC settings consisted of two simultaneous independent runs with four chains each that were run for 10 million generations and sampled every 100th generation, thus yielding 100,000 trees. After eliminating $25 \%$ of the samples as burn-in, a consensus tree was built. Statistical 
Table 1. Sequences of the oligonucleotide primers used, along with their respective target genes and the size of the amplified fragment.

\begin{tabular}{|c|c|c|c|c|c|}
\hline Primer & Gen & Organism & Nucleotide sequence (5'-3') & $\begin{array}{l}\text { Fragment } \\
\text { size }\end{array}$ & Reference \\
\hline CS239 F & $g l t \mathrm{~A}$ & Rickettsia spp. & GCTCTTCTCATCCTATGGCTATTAT & $834 \mathrm{bp}$ & (LABRUNA et al., 2004) \\
\hline CS1069 R & & & CAGGGTCTTCGTGCATTTCTT & & \\
\hline BorFlaF1 & $f l a \mathrm{~B}$ & Borrelia spp. & TACATCAGCTATTAATGCTTCAAGAA & $740 \mathrm{pb}$ & (BLANCO et al., 2017) \\
\hline BorFlaR1 & & & GCAATCATWGCCATTGCRGATTG & & \\
\hline BorFlaF2 & & & CTGATGATGCTGCTGGWATGG & & \\
\hline BorFlaR2 & & & TCATCTGTCATTRTWGCATCTT & & \\
\hline Hptf & $h p t$ & Borrelia spp. & GCAGAYATTACAAGAGARATGG & $433 \mathrm{pb}$ & (MCCOY et al., 2014) \\
\hline $\mathrm{HptR}$ & & & CYTCRTCACCCCATTGAGTTCC & & \\
\hline $\operatorname{glpQ}+1$ & $g l p Q$ & Borrelia spp. & GGGGTTCTGTTACTGCTAGTGCCATTAC & $817 \mathrm{pb}$ & (SCHWAN et al., 2005) \\
\hline Glpq - 1 & & & CAATTTTAGATATGTCTTTACCTTGTTGTTTATGCC & & \\
\hline BT-F3 & $18 \mathrm{~S}$ rRNA & Piroplasmida & TGGGGGGAGTATGGTCGCAAG & $650 \mathrm{pb}$ & (SEO et al., 2013) \\
\hline BT-R3 & & Order & СTCСТTCСTTTAAGTGATAAG & & \\
\hline DSB-330 & Dsb & Ehrlichia spp. & GATGATGCTTGAAGATATSAAACAAAT & $349 \mathrm{bp}$ & (ALMEIDA et al., 2013) \\
\hline DSB-380 & & & ATTTTTAGRGATTTTCCAATACTTGG & & \\
\hline DSB-720 & & & СTATTTTACTTCTTAAAGTTGATAWATC & & \\
\hline ge $3 \mathrm{~A}$ & $16 \mathrm{~S}$ rRNA & Anaplasma bovis, & CACATGCAAGTCGAACGGAT TATTC & $546 \mathrm{bp}$ & (MASSUNG et al., 1998) \\
\hline ge10R & & Anaplasma platys & TTCCGTTAAGAAGGATCTAATCTCC & & \\
\hline ge9f & & and Anaplasma & AACGGATTATTCTTTATAGCTTGCT & & \\
\hline ge2 & & phagocytophilum & GGCAGTATTAAAAGCAGCTCCAGG & & \\
\hline
\end{tabular}

support of the clades was measured by a heuristic search, with 1000 bootstrap replicates and the Bayesian posterior probabilities.

The study was evaluated and approved by the Animal Experimentation Ethics Committee of the Federal Rural University of Rio de Janeiro and was conducted with the permission of IBAMA; process num. 43917/3/2505369.

\section{Results and Discussion}

Detailed data of the tick-bird association that was reported in the current study can be found in Table 2 . In total, 33 birds were captured, representing three orders, seven families, and 20 species, of which 14 (42\%) of 9 species (45\%) were parasitized by 22 immature forms of Amblyomma spp. Birds of the order Passeriformes were the most frequent, with 27 (82\%) specimens captured, divided into 5 families and 15 species, corroborating with the data published in previous literature (LUZ \& FACCINI, 2013; OGRZEWALSKA \& PINTER, 2016). No ticks were recorded on the following bird species: Passeriformes - Myiozetetes similis, Coereba flaveola, Sicalis flaveola, Tangara cayana, Tangara sayaca, Troglodytes musculus; Columbiformes - Leptotila rufaxilla, Geotrygon montana, Columbina talpacoti; Cuculiformes - Piaya cayana. However, there are numerous records of these species in association with ticks in different biomes in Brazil (LABRUNA et al., 2007; LUGARINI et al., 2015; LUZ et al., 2016; OGRZEWALSKA \& PINTER, 2016).

After the laboratory analysis, all ticks were identified as nymphs of Amblyomma longirostre. In general, the infestations found in the birds were low, and were not exceeding the average intensity of 2.5/tick per bird. All the ticks were collected in the head and neck regions, and similar parasitic intensities have also been reported in the Atlantic Forest (LUZ \& FACCINI, 2013).
The immature parasitism of $A$. longirostre in wild birds has been reported throughout the neo-tropical region, especially on birds from the Passeriformes sub-group (LABRUNA et al., 2007; NAVA et al., 2010; LUZ \& FACCINI, 2013, 2016). There are also reports of this species of tick on birds in the neartic region, but these arthropods do not have populations established in this region (GUGLIELMONE et al., 2014). These findings reinforce the importance of wild birds in the maintenance and dispersion of this ectoparasite, as they are the main group of hosts for immature forms of $A$. longirostre in the wild environment. On the other hand, the adult stage of $A$. longirostre has been recorded mainly to be on neo-tropical porcupines of the family Erethizontidae, followed by occasional records on a variety of wild and domestic mammals of the families Cervidae, Canidae, Mustelidae, Phyllostomidae, Equidae, Bradypodidae and Sciuridae (BARROS-BATTESTI et al., 2006; GUGLIELMONE et al., 2014).

The arboreal habits of its primary hosts may justify the presence of the immature forms on birds that tend to share similar habits, suggesting an arboreal cycle for $A$. longirostre (LABRUNA et al., 2007).

Molecular analysis by the CS239/CS1069 primers revealed a 838 bp amplification of the gltA gene of Rickettsia spp. in three samples of $A$. longirostre that were collected on birds of three different species: Saltator similis, Turdus leucomelas, and Tangara seledon. The products sequenced from one sample had a $100 \%$ identity rate with the Rickettsia bellii isolated H3 (access in the GenBank: KJ534309). With the other two, the identity was $100 \%$ with Rickettsia sp. strain AL and the Rickettsia sp. Aranha strain (access in the GenBank: EU274654 and AY360216, respectively) both currently correlated with Rickettsia amblyommatis (OGRZEWALSKA et al., 2011; KARPATHY et al., 2016), as shown in Figure 1. These agents have already been described 
Table 2. Prevalence and mean intensity of infestation by ticks collected in birds in the Serra dos Órgãos National Park and Guapimirim.

\begin{tabular}{|c|c|c|c|c|c|c|c|c|}
\hline ORDER & FAMILY & SPECIES & BC & IB & PI (\%) & NTC & MII & STI \\
\hline \multirow[t]{15}{*}{ Passeriformes } & Tyrannidae & Pitangus sulphuratus & 1 & 1 & $100(\%)$ & 1 & 1 & Amblyomma longirostre \\
\hline & & Mionectes oleagineus & 1 & 1 & $100(\%)$ & 2 & 2 & Amblyomma longirostre \\
\hline & & Myiozetetes similis & 1 & 0 & & & & \\
\hline & Pipridae & Manacus manacus & 3 & 3 & $100(\%)$ & 5 & 1.6 & Amblyomma longirostre \\
\hline & Turdidade & Turdus rufiventris & 1 & 1 & $100(\%)$ & 1 & 1 & Amblyomma longirostre \\
\hline & & Turdus leucomelas & 4 & 2 & $50(\%)$ & 5 & 2.5 & Amblyomma longirostre \\
\hline & & Turdus amaurochalinus & 2 & 1 & $50(\%)$ & 1 & 1 & Amblyomma longirostre \\
\hline & Thraupidae & Coereba flaveola & 1 & 0 & & & & \\
\hline & & Sicalis flaveola & 1 & 0 & & & & \\
\hline & & Tachyphomnus coronatus & 4 & 2 & $50(\%)$ & 3 & 1.5 & Amblyomma longirostre \\
\hline & & Tangara seledon & 3 & 2 & $66(\%)$ & 2 & 1 & Amblyomma longirostre \\
\hline & & Tangara cayana & 2 & 0 & & & & \\
\hline & & Tangara sayaca & 1 & 0 & & & & \\
\hline & & Saltator similis & 1 & 1 & $100(\%)$ & 2 & 2 & Amblyomma longirostre \\
\hline & Troglodytidae & Troglodytes musculus & 1 & 0 & & & & \\
\hline \multirow[t]{3}{*}{ Columbiformes } & Columbidae & Leptotila rufaxilla & 2 & 0 & & & & \\
\hline & & Geotrygon montana & 1 & 0 & & & & \\
\hline & & Columbina talpacoti & 2 & 0 & & & & \\
\hline Cuculiformes & Cuculidae & Piaya cayana & 1 & 0 & & & & \\
\hline
\end{tabular}

BC: number of birds captured; IB: infested birds; PI: prevalence of infestation; NTC: number of ticks collected; MII: mean intensity of infestation; STI: Species of tick identified.

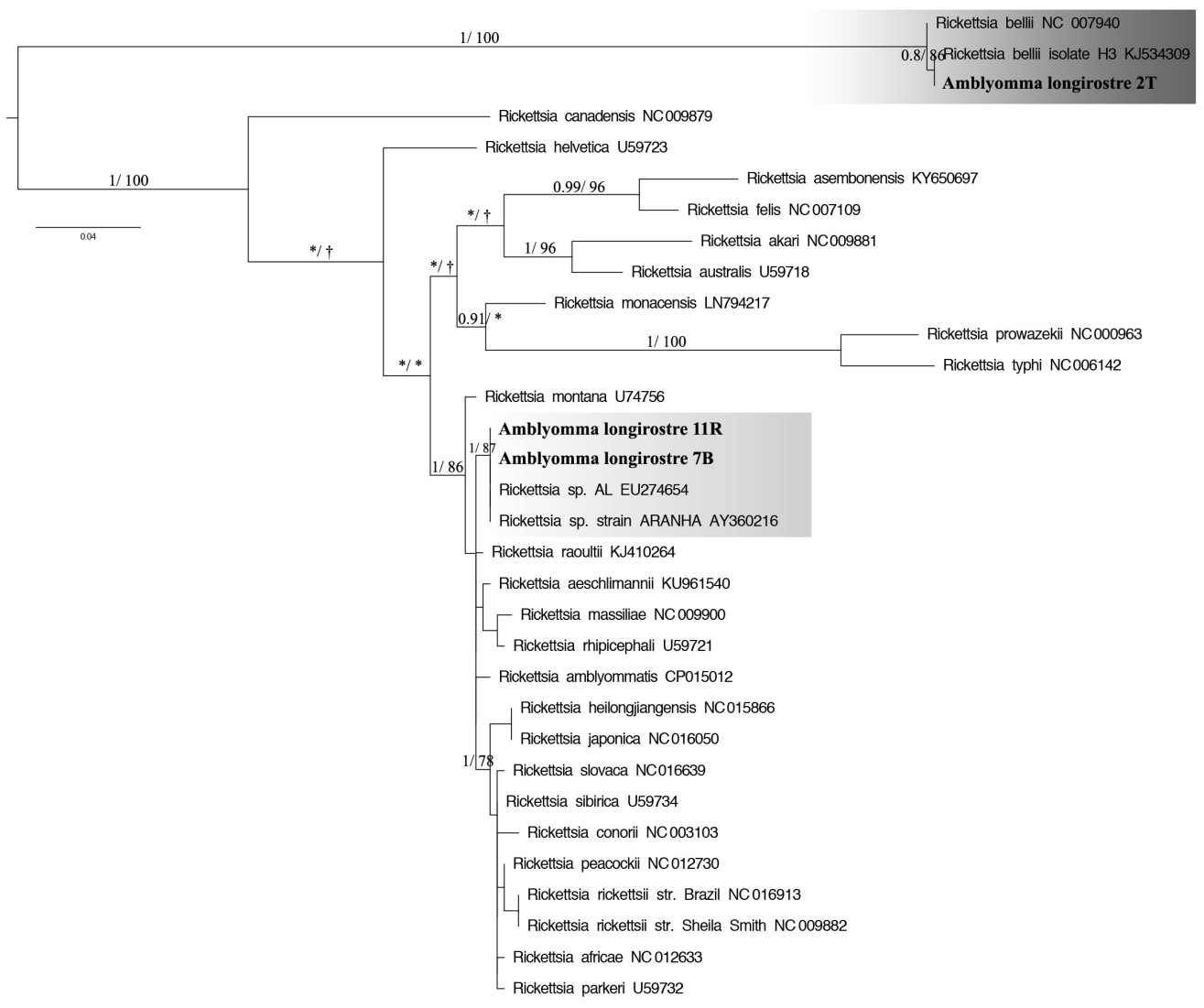

Figure 1. Phylogenetic tree based on the gltA gene (734nt) sequences of Rickettsia, using ML and Bayesian methods. Numbers (>0.7/>70\%) above the branches indicate posterior node probabilities or bootstrap values (MrBayes/ML). ${ }^{*}$ Indicate values below $0.7 / 70$. $†$ Exhibited difference between ML and MrBayes tree-building method topology. The scale bars indicate an evolutionary distance of 0.04 substitutions per position in the sequence and the branch labels include GenBank accession numbers. The Tamura 3-parameter model with gamma-distributed heterogeneity (T92 + G) was selected as the best-fit evolutionary model. 


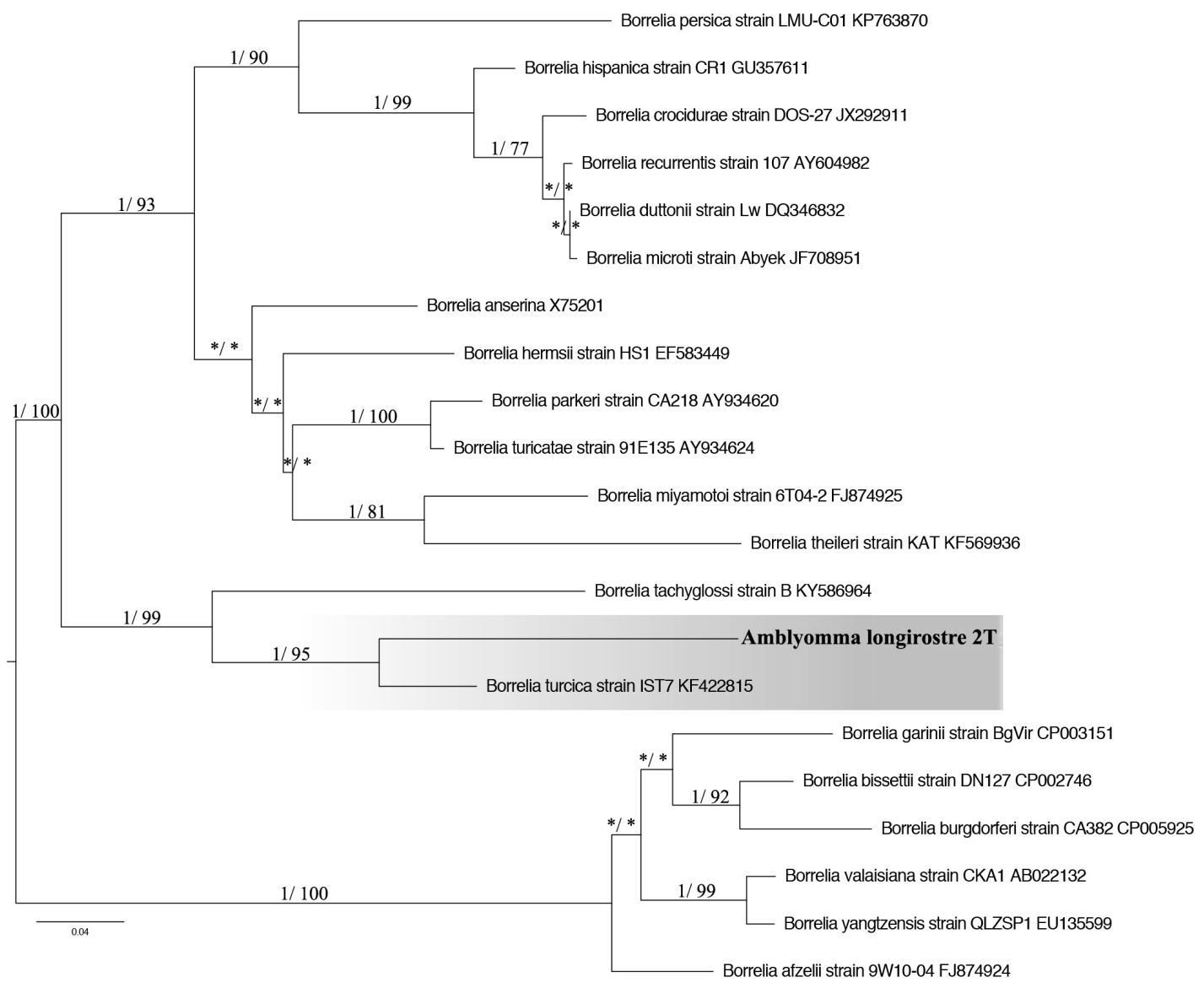

Figure 2. Phylogenetic tree based on the flaB gene (652nt) sequences of Borrelia, using ML and Bayesian methods. Numbers (>0.7/>70\%) above the branches indicate posterior node probabilities or bootstrap values (MrBayes/ML). *Indicate values below $0.7 / 70$. $†$ Exhibited difference between ML and MrBayes tree-building method topology. The scale bars indicate an evolutionary distance of 0.04 substitutions per position in the sequence. The branch labels include GenBank accession numbers. The Tamura 3-parameter model with gamma-distributed heterogeneity $(\mathrm{T} 92+\mathrm{G})$ was selected as the best-fit evolutionary model.

in Brazil by Ogrzewalska et al. (2008) in the same tick species, A. longirostre. However, it was on birds of different species.

A sample of $A$. longirostre from Tangara seledon was positive for Borrelia spp. when using primers BorFlaF1/BorFlaR1 and BorFlaF2/BorFlaR2, which amplifies 740 bp of the flagellin B gene.

This sample presented a $91 \%$ identity rate with Borrelia turcica IST7 (access in the genbank: KF422815) (Figure 2), found in Hyalomma aegyptium. The partial sequence of the flaB gene also showed 99\% similarity (coverage of $47 \%$ e $41 \%$ ) with Borrelia sp. TX-Amac2 and Borrelia sp. F3 (access number KP861337 and KF395231), and both were found in A. maculatum that infested humans in the United States of America (MITCHELL et al., 2016).

The primers that target the hpt and glpQ genes of Borrelia spp. did not amplify products, probably because it is a conventional PCR and the sample does not have DNA in concentration sufficient for the amplification. Although $A$. longirostre has been described to infest humans in its immature stages (GUGLIELMONE et al., 2006), it cannot be said that the transmission may occur, because it is not aware of the pathogenic potential of the bacteria. This finding is of great importance for the literature, because it is the first time a report has pertained to the presence of Borrelia sp. in A. longirostre. There was no DNA from Anaplasma sp., Ehrlichia sp., and protozoa of the order Piroplasmida infecting the ticks in the present study. Therefore, bacteria of the genera Borrelia and Rickettsia can be found in A. longirostre that parasitize birds in the state of Rio de Janeiro.

\section{Acknowledgements}

We would like to express our gratitude to the Conselho Nacional de Desenvolvimento Científico e Tecnológico - CNPq (A.H.F. 305480/2013-8) and Fundação de Apoio à pesquisa no estado do Rio de Janeiro - FAPERJ (A.H.F., grant number E 26/201.144/2014), for their financial support.

\section{References}

Almeida AP, Souza TD, Marcili A, Labruna MB. Novel Ehrlichia and Hepatozoon agents infecting the crab-eating fox (Cerdocyon thous) in southeastern Brazil. J Med Entomol 2013; 50(3): 640-646. http://dx.doi. org/10.1603/ME12272. PMid:23802461. 
Barros-Battesti DM, Arzua M, Bechara GH. Carrapatos de importância médico-veterinária da regiáo neotropical: um guia ilustrado para identificação de espécies. $1^{a}$ ed. São Paulo: Vox/ICTTD-3/Butantan, 2006.

Blanco CM, Teixeira BR, da Silva AG, de Oliveira RC, Strecht L, Ogrzewalska M, et al. Microorganisms in ticks (Acari: Ixodidae) collected on marsupials and rodents from Santa Catarina, Paraná and Mato Grosso do Sul states, Brazil. Ticks Tick Borne Dis 2017; 8(1): 90-98. http://dx.doi. org/10.1016/j.ttbdis.2016.10.003. PMid:27769655.

Budachetri K, Williams J, Mukherjee N, Sellers M, Moore F, Karim S. The microbiome of neotropical ticks parasitizing on passerine migratory birds. Ticks Tick Borne Dis 2017; 8(1): 170-173. http://dx.doi.org/10.1016/j. ttbdis.2016.10.014. PMid:27802919.

Capligina V, Salmane I, Keiss O, Vilks K, Japina K, Baumanis V, et al. Prevalence of tick-borne pathogens in ticks collected from migratory birds in Latvia. Ticks Tick Borne Dis 2014; 5(1): 75-81. http://dx.doi. org/10.1016/j.ttbdis.2013.08.007. PMid:24246709.

Comitê Brasileiro de Registros Ornitológicos - CBRO. Listas das aves do Brasil. 10ª ed. Florianópolis: CBRO; 2014.

Erwin JA, Fitak RR, Dwyer JF, Morrison JL, Culver M. Molecular detection of bacteria in the families Rickettsiaceae and Anaplasmataceae in northern crested caracaras (Caracara cheriway). Ticks Tick Borne Dis 2016; 7(3): 470-474. http://dx.doi.org/10.1016/j.ttbdis.2016.01.015. PMid:26837860.

Gouy M, Guindon S, Gascuel O. SeaView version 4: A multiplatform graphical user interface for sequence alignment and phylogenetic tree building. Mol Biol Evol 2010; 27(2): 221-224. http://dx.doi.org/10.1093/ molbev/msp259. PMid:19854763.

Guglielmone A, Beati L, Barros-Battesti D, Labruna M, Nava S, Venzal J, et al. Ticks (Ixodidae) on humans in South America. Exp Appl Acarol 2006; 40(2): 83-100. http://dx.doi.org/10.1007/s10493-006-9027-0. PMid:17103085.

Guglielmone AA, Robbins RG, Apanaskevich DA, Petney TN, Estrada-Peña A, Horak IG. The hard ticks of the world (Acari: Ixodida: Ixodidae). $1^{\text {a }}$ ed. London: Springer; 2014. http://dx.doi.org/10.1007/978-94-007-7497-1.

Hubálek Z. An annotated checklist of pathogenic microorganisms associated with migratory birds. J Wildl Dis 2004; 40(4): 639-659. http://dx.doi. org/10.7589/0090-3558-40.4.639. PMid:15650082.

Karpathy SE, Slater KS, Goldsmith CS, Nicholson WL, Paddock CD. Rickettsia amblyommatis sp. nov., a spotted fever group Rickettsia associated with multiple species of Amblyomma ticks in North Central and South America. Int J Syst Evol Microbiol 2016; 66(12): 5236-5243. http:// dx.doi.org/10.1099/ijsem.0.001502. PMid:27638476.

Kumar S, Stecher G, Tamura K. MEGA7: Molecular Evolutionary Genetics Analysis Version 7.0 for Bigger Datasets. Mol Biol Evol 2016; 33(7): 18701874. http://dx.doi.org/10.1093/molbev/msw054. PMid:27004904.

Labruna MB, Sanfilippo LF, Demetrio C, Menezes AC, Pinter A, Guglielmone AA, et al. Ticks collected on birds in the state of São Paulo, Brazil. Exp ApplAcarol 2007; 43(2): 147-160. http://dx.doi.org/10.1007/ s10493-007-9106-x. PMid:17882514.

Labruna MB, Whitworth T, Horta MC, Bouyer DH, McBride JW, Pinter A, et al. Rickettsia species infecting Amblyomma cooperi ticks from an area in the state of Sao Paulo, Brazil, where Brazilian spotted fever is endemic. J Clin Microbiol 2004; 42(1): 90-98. http://dx.doi.org/10.1128/ JCM.42.1.90-98.2004. PMid:14715737.

Loss SR, Noden BH, Hamer GL, Hamer SA. A quantitative synthesis of the role of birds in carrying ticks and tick-borne pathogens in North
America. Oecologia 2016; 182(4): 947-959. http://dx.doi.org/10.1007/ s00442-016-3731-1. PMid:27670413.

Lugarini C, Martins TF, Ogrzewalska M, de Vasconcelos NC, Ellis VA, de Oliveira JB, et al. Rickettsial agents in avian ixodid ticks in northeast Brazil. Ticks Tick Borne Dis 2015; 6(3): 364-375. http://dx.doi.org/10.1016/j. ttbdis.2015.02.011. PMid:25800099.

Luz HR, Faccini JLH. Parasitismo por carrapatos em anuros no Brasil. Revisão. Vet Zootec 2013; 20: 100-111.

Luz HR, Faccini JL, Landulfo GA, Berto BP, Ferreira I. Bird ticks in an area of the Cerrado of Minas Gerais State, southeast Brazil. Exp Appl Acarol 2012; 58(1): 89-99. http://dx.doi.org/10.1007/s10493-0129572-7. PMid:22729500.

Luz HR, Faccini JLH, Landulfo GA, Costa Neto SF, Famadas KM. New records for Amblyomma sculptum (Ixodidae) on non-passerine birds in Brazil. Rev Bras Parasitol Vet 2016; 25(1): 124-126. http://dx.doi. org/10.1590/S1984-29612016004. PMid:27007247.

Martins TF, Onofrio VC, Barros-Battesti DM, Labruna MB. Nymphs of the genus Amblyomma (Acari: Ixodidae) of Brazil: descriptions, redescriptions, and identification key. Ticks Tick Borne Dis 2010; 1(2): 75-99. http://dx.doi.org/10.1016/j.ttbdis.2010.03.002. PMid:21771514.

Massung RF, Slater K, Owens JH, Nicholson WL, Mather TN, Solberg VB, et al. Nested PCR assay for detection of granulocytic ehrlichiae. $J$ Clin Microbiol 1998; 36(4): 1090-1095. PMid:9542943.

McCoy BN, Maïga O, Schwan TG. Detection of Borrelia theileri in Rhipicephalus geigyi from Mali. Ticks Tick Borne Dis 2014; 5(4): 401403. http://dx.doi.org/10.1016/j.ttbdis.2014.01.007. PMid:24709337.

Mitchell EA, Williamson PC, Billingsley PM, Seals JP, Ferguson EE, Allen MS. Frequency and distribution of Rickettsiae, Borreliae, and Ehrlichiae Detected in Human-Parasitizing Ticks, Texas, USA. Emerg Infect Dis 2016; 22(2): 312-315. http://dx.doi.org/10.3201/eid2202.150469. PMid:26811941.

Nava S, Venzal JM, Labruna MB, Mastropaolo M, González EM, Mangold AJ, et al. Hosts, distribution and genetic divergence (16S rDNA) of Amblyomma dubitatum (Acari: Ixodidae). Exp Appl Acarol 2010; 51(4): 335-351. http://dx.doi.org/10.1007/s10493-009-9331-6. PMid:20084537.

Ogrzewalska M, Pacheco RC, Uezu A, Ferreira F, Labruna MB. Ticks (Acari: Ixodidae) infesting wild birds in an Atlantic forest area in the state of São Paulo, Brazil, with isolation of Rickettsia from the tick Amblyomma longirostre. J Med Entomol 2008; 45(4): 770-774. http:// dx.doi.org/10.1093/jmedent/45.4.770. PMid:18714882.

Ogrzewalska M, Pinter A. Ticks (Acari: Ixodidae) as ectoparasites of Brazilian wild birds and their association with rickettsial diseases. Braz J Vet Res Anim Sci 2016; 53(1): 1-31. http://dx.doi.org/10.11606/ issn.1678-4456.v53i1p1-31.

Ogrzewalska M, Uezu A, Labruna MB. Ticks (Acari: Ixodidae) infesting wild birds in the eastern Amazon, northern Brazil, with notes on rickettsial infection in ticks. Parasitol Res 2010; 106(4): 809-816. http://dx.doi. org/10.1007/s00436-010-1733-1. PMid:20140452.

Ogrzewalska M, Uezu A, Labruna MB. Ticks (Acari: Ixodidae) infesting wild birds in the Atlantic Forest in northeastern Brazil, with notes on rickettsial infection in ticks. Parasitol Res 2011; 108(3): 665-670. http:// dx.doi.org/10.1007/s00436-010-2111-8. PMid:20953629.

Palomar AM, Santibáńez P, Mazuelas D, Roncero L, Santibáñez S, Portillo A, et al. Role of birds in dispersal of etiologic agents of tick-borne 
zoonoses, Spain, 2009. Emerg Infect Dis 2012; 18(7): 1188-1191. http:// dx.doi.org/10.3201/eid1807.111777. PMid:22709801.

Parola P, Paddock CD, Socolovschi C, Labruna MB, Mediannikov O, Kernif T, et al. Update on tick- borne rickettsioses around the world: A geographic approach. Clin Microbiol Rev 2013; 26(4): 657-702. http:// dx.doi.org/10.1128/CMR.00032-13. PMid:24092850.

Ramos DG, Melo AL, Martins TF, Alves AS, Pacheco TA, Pinto LB, et al. Rickettsial infection in ticks from wild birds from Cerrado and the Pantanal region of Mato Grosso, midwestern Brazil. Ticks Tick Borne Dis 2015; 6(6): 836-842. http://dx.doi.org/10.1016/j.ttbdis.2015.07.013. PMid:26232933.

Sanches GS, Martins TF, Lopes IT, Costa LF, Nunes PH, Camargo-Mathias MI, et al. Ticks infesting birds in Atlantic Forest fragments in Rio Claro, State of Sao Paulo, Brazil. Rev Bras Parasitol Vet 2013; 22(1): 6-12. http:// dx.doi.org/10.1590/S1984-29612013000100003. PMid:24252949.

Santolin IDAC, Famadas KM, McIntosh D. Detecção e identificação de espécies de Rickettsia em carrapatos coletados de aves silvestres no Brasil pela PCR-RFLP. Rev Bras Med Vet 2013; 35(Supl.2): 68-73.
Schwan TG, Raffel SJ, Schrumpf ME, Policastro PF, Rawlings JA, Lane RS, et al. Phylogenetic analysis of the spirochetes Borrelia parkeri and Borrelia turicatae and the potential for tick-borne relapsing fever in Florida. J Clin Microbiol 2005; 43(8): 3851-3859. http://dx.doi.org/10.1128/ JCM.43.8.3851-3859.2005. PMid:16081922.

Scott JD, Lee MK, Fernando K, Durden LA, Jorgensen DR, Mak S, et al. Detection of Lyme disease spirochete, Borrelia burgdorferi sensu lato, including three novel genotypes in ticks (Acari: Ixodidae) collected from songbirds (Passeriformes) across Canada. J Vector Ecol 2010; 35(1): 124-139. http://dx.doi.org/10.1111/j.1948-7134.2010.00068.x. PMid:20618658.

Seo MG, Yun SH, Choi SK, Cho GJ, Park YS, Cho KH, et al. Molecular and phylogenetic analysis of equine piroplasms in the Republic of Korea. Res Vet Sci 2013; 94(3): 579-583. http://dx.doi.org/10.1016/j. rvsc.2013.01.014. PMid:23415067.

Soares HS, Barbieri AR, Martins TF, Minervino AH, de Lima JT, Marcili A, et al. Ticks and rickettsial infection in the wildlife of two regions of the Brazilian Amazon. Exp Appl Acarol 2015; 65(1): 125-140. http:// dx.doi.org/10.1007/s10493-014-9851-6. PMid:25273064. 